\title{
Preponderance and possible factors associated to musculoskeletal symptoms in metals industry workers
}

\author{
Eunice Tokars ${ }^{\mathrm{a}}$ *, Antonio Renato Pereira Moro ${ }^{\mathrm{a}}$, Gabriel Grabner dos Santos ${ }^{\mathrm{b}}$. \\ ${ }^{a}$ Post-graduation Program in Production Engineering, Ergonomics, Federal University of Santa Catarina, \\ SC, Brazil. \\ ${ }^{\mathrm{b}}$ Physiotherapist in Curitiba, Brazil.
}

\begin{abstract}
The objective of this study was to determine the prevalence of complaints of musculoskeletal pain in workers following the metallurgical establishing a relationship with the sociodemographic profile and perception of professionals about the cause of symptoms. A descriptive cross-sectional study was conducted in the following metallurgical enterprises in the city of Curitiba, Brazil. The sample consisted of 50 individuals. The instrument used for data collection was the "Nordic Questionnaire of musculoskeletal symptoms" including demographic data and verifying the level of significance (0.05). There was a prevalence of low back pain, hip and lower limbs $(92 \%)$, especially those who work more than one year, and $82 \%$ reported relationship between pain and work. The symptoms in the lumbar region grouped the dorsal region was more related to activity performed with the p-value of 0.000 . The possible relationship between pain and the work reveals the need for an ergonomic program that allows improved quality of life for the metallurgical.
\end{abstract}

Keywords: metalworkers, musculoskeletal disorders, ergonomics.

\section{Introduction}

The Work-Related Musculoskeletal Disorders (MSDs) are the main group of occupational diseases not only in Brazil but in many countries and professions. The high prevalence has been explained by changes in work and setting goals and productivity, product quality and services and increased market competitiveness disregarding the limits of physical and psychosocial workers [1]. The restructuring of the metal-mechanic sector has been blamed for the deterioration of working conditions triggering the disease [2].

The musculoskeletal disorders related to work has its own characteristics and correlation directly or indirectly with the work the individual performs [3].

The causes are multifactorial including biological, psychological and social [4] and affect the muscles, tendons, synovial, nerves, ligaments and fascia, singly or combined, with or without degeneration of tissues, which in addition to pain may have paresthesia, tiredness and tingling in the affected limb and in some cases, be confused with muscle fatigue $[2,4,5]$.

The diagnostic inaccuracy often complicates the process of association between the disease and the worker's employment history [6]

However, regardless of the factors it is essential that both the company and workers are aware that it is impossible to produce good quality when the pain and discomfort are now present in the daily lives of workers $[2,5]$.

Musculoskeletal disorders continue to be a major source of disability, however, the understanding their causes, and especially those that are work-related, remain very important to primary prevention [7].

The objective of this study was to determine the prevalence of complaints of musculoskeletal

*Adress for correspondence: Eunice Tokars. Universidade Federal de Santa Catarina - Programa de Pós Graduação em Engenharia de Produção - Ergonomia - Campus Universitário, Trindade, Florianópolis, SC, Brasil. CEP: 88040-970; Tel. (55) 48-37218530. email: eunice.tokars@utp.br 
pain in workers following the metallurgical establishing a relationship with the sociodemographic profile and perception of professionals about the cause of symptoms.

\section{Method}

A descriptive cross-sectional study was conducted in the following metallurgical enterprises in the city of Curitiba, Brazil.

\subsection{Participants}

The sample consisted of 50 individuals with any formal, able to work as certified occupational health who conduct activities of assemblers, production helpers, welders, machine operators and painters in body position on foot for almost the entire workday.

\subsection{Instruments}

The instrument used to collect data, including demographic data, was the "Nordic Questionnaire of musculoskeletal symptoms" [8], considering the level of significance (0.05).

\subsection{Data Analysis}

For statistical analysis was applied Fisher's exact test, for the estimate of the difference, the confidence verifying the estimate of the difference, the confidence interval and $p$ value of the test to demonstrate differences in the proportions are the same or statistically different. If the value is less than the significance level (for 0.05 ) then the difference between two is significant.

\section{Results}

There was a predominance of male labor with $82 \%$ and $64 \%$ owned by young age (fifteen to thirty years), $34 \%$ in middle age (the thirty-one to forty-five years) and $2 \%$ at the age of change ( forty-six to sixty years), all completed high school. Only 4\% are smokers and most performs some physical activity, and $40 \%$ play football, $20 \%$ engage in strength training, $10 \%$ race and $30 \%$ have other physical practices.It was observed that $92 \%$ reported some discomfort in at least anatomical region in the last year. Perform extra activities was confirmed by $84.7 \%$ of individuals.

The graphic 1 presents the number of complaints of pain or numbness and frequency of discomfort according to the body segments (rarely, often, and always). The region of greatest complaint of discomfort in professionals was the lumbar (27), followed by the hip / lower limb (LL) (26), the dorsal region (23), shoulder (16), arm (13), neck (13), wrists, hands and fingers (11), forearm (7) and elbow (4).

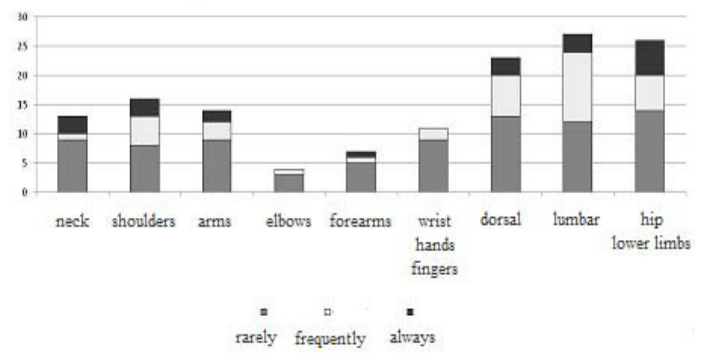

Graph 1 - Number and frequency of complaints of pain or numbness in accordance with the body segments

The table 1 presents the areas of the body and regularity with which report some discomfort, pain or numbness. The region of the hip / lower limb was the most cited, $12 \%$ always feel discomfort and $28 \%$ rarely, surpassing the lumbar region. The regions of wrists, hands and fingers, forearms and elbows had little or no reports about the frequency at its most critical.

\section{Table 1}

Body areas and frequency of reports of discomfort, pain or numbness

\begin{tabular}{|c|c|c|c|c|c|c|c|c|c|}
\hline \multirow{3}{*}{$\frac{\text { anatomic reg̣ion }}{\text { neck }}$} & \multicolumn{2}{|c|}{ non } & \multicolumn{2}{|c|}{ farely } & \multirow{2}{*}{\multicolumn{2}{|c|}{ frequently }} & \multicolumn{3}{|c|}{ allways } \\
\hline & |frequents & alative fre & frequen: & elative fres & & & a) frequent! & relative fre & Total \\
\hline & 37 & $74 \%$ & 9 & $18 \%$ & 1 & $2 \%$ & 3 & $6 \%$ & 50 \\
\hline shovders & 34 & $68 \%$ & 8 & $16 \%$ & 5 & $10 \%$ & 3 & $6 \%$ & 50 \\
\hline arms & 36 & $72 \%$ & 9 & $18 \%$ & 3 & $6 \%$ & 2 & $4 \%$ & 50 \\
\hline ellbows & 46 & $92 \%$ & 3 & $6 \%$ & 1 & $2 \%$ & 0 & $0 \%$ & so \\
\hline forearms & 43 & $86 \%$ & 5 & $10 \%$ & 1 & $2 \%$ & 1 & $2 \%$ & 50 \\
\hline wrist hand fingers & 39 & $78 \%$ & 9 & $18 \%$ & ${ }^{2}$ & $4 \%$ & 0 & $0 \%$ & 50 \\
\hline dorsal & 27 & $54 \%$ & 13 & $26 \%$ & 7 & $14 \%$ & 3 & $6 \%$ & 50 \\
\hline lombar & 23 & $46 \%$ & 12 & $24 \%$ & 12 & $24 \%$ & 3 & $6 \%$ & 50 \\
\hline hiplower libs & 24 & $48 \%$ & 14 & $28 \%$ & 6 & $12 \%$ & 6 & $12 \%$ & 50 \\
\hline
\end{tabular}

The association between working time and musculoskeletal symptoms, between lifestyle and musculoskeletal symptoms (physical activitysedentary and nonsmokers-asmokers) and between gender and musculoskeletal symptoms was no significant. But there were significant in the association between work and musculoskeletal symptoms.

When asked about the relationship of musculoskeletal complaints with the work, $82 \%$ reported at least one anatomical region affected by symptoms due to work (table 2).

The presence of symptoms in the lumbar region grouped the dorsal region was more related to the activity performed by workers, followed by regions of the neck, shoulders and upper limbs and hips / legs. For this relationship was significant difference in the lumbar and 
dorsalrigion between those who agree and not agreethat the pain is related to the work. For the others regions, there was not significant difference.

Table 2

Association between work and musculoskeletal symptoms

\begin{tabular}{cccc}
\hline & lumbar and dorsal & hip and lower limbs & neck, shovders,arms \\
\hline Symptoms related to work & $75 \%$ & $46 \%$ & $60 \%$ \\
Symptoms unrelated & $25 \%$ & $54 \%$ & $40 \%$ \\
\hline & & & \\
Test of difference & & & \\
\hline difference estimative & $50 \%$ & $-8 \%$ & $20 \%$ \\
confidence interval & $-28,78 \% ; 71,22 \%$ & $-34,79 \% ; 19,41 \%$ & $-4,79 \%: 44,79 \%$ \\
P.valve & 0,000 & 0,579 & 0,121 \\
& & & \\
Fischer's exact test & & & \\
\hline P.valve & 0,765 & 0,782 & 0,196
\end{tabular}

\section{Discussion}

All workers completed the high school, a fact that contributed significantly to the collection of data due to easy understanding and interpretation of the questionnaire. According to the results, it was found that most of the sample consisted of males, with a predominance of young age (15 to 30 years). While all were considered fit for work, healthy and absence of disease, there was a prevalence of low back pain, hip and lower limbs $(92 \%)$. Professionals same activity showed a $75.2 \%$ rate of pain complaints in the last 12 months[5].

The standing posture required during the journey, being forbidden to sit due to the characteristics of tasks, probably contributed to the rates of pain complaints especially when associated with rotation and tilt the trunk forward, as well as risk factors for neck pain, shoulder and legs [9].

Workers with an employment contract for a period less than one year had fewer musculoskeletal symptoms in relation to workers who have had a longer period. The occurrence of musculoskeletal disorders among workers with up to two years of occupation remains high since 1996, representing $20 \%$ of diagnosed cases[10]. There was no significant association of musculoskeletal symptoms between smokers and nonsmokers, but studies show this association [11]. Age (40-59 years), low education, high body mass index, smoking, weight lifting and repetitive movements associated with high psychological demands, low decision-making power and clutter of work can contribute to the occurrence of disease and absence from work [12].

The physically active had a lower incidence of pain in all regions compared with the sedentary. Physical inactivity is recognized as a contributing factor to the lack of health $[9,10]$. As for the relationship between pain and work,
$82 \%$ reported at least one anatomical region affected. The presence of symptoms in the lumbar region grouped the dorsal region was more related to the activity performed by the workers.

The comparison between the association of gender and pain symptoms in the regions grouped: hips / legs and neck / shoulder / upper limbs were of females. In this regard, the hormonal difference and muscle mass, body composition and anthropometry of women compared to men may represent, for this group, a risk of painful symptoms [9].

The results demonstrated the need for early detection and prevention of pain state to prevent the development of psychophysical constraints and absences from work. It is suggested the establishment of an ergonomic intervention program to foster a better quality of life for the metalworkers.

\section{References}

[1] A.M.C. Araujo; E.M. Oliveira Reestruturação Produtiva e Saúde no Setor Metalúrgico: a percepção das trabalhadoras. Sociedade e Estado, Brasília, jan./abr. 2006.

[2] G.L Chiavegato Filho; A Pereira; LER/DORT: Multifatorialidade etiológica e modelos explicativos. Interface (Botucatu) Set./Fev. 2004.

[3] Daniela Colombini, E.Occhipinti, M.Fanti, Meto do OCRA per 1' analisi e la prevenzione Del rischio da movimenti ripetuti. Manuale per la valutazione e la gestione Del rischio.Milão: FrancoAngeli,2005

[4] J.C.Bachiega. Sintomas de distúrbios osteomusculares relacionados à atividade de cirurgiões-dentistas brasileiros. Mestrado em Ciências da Reabilitação. Universidade Nove de Julho, São Paulo, 2009.

[5] D. Picoloto; E.Silveira; Prevalência de sintomas osteomusculares e fatores associados em trabalhadores de uma indústria metalúrgica de Canoas - RS. Ciência e saúde coletiva, Rio de Janeiro, março/abril. 2008.

[6] V.G Augusto, R.F. Sampaio, Um olhar sobre as LER/DORT no contexto clínico do fisioterapeuta. Revista Brasileira de Fisioterapia vol.12 no.1 São Carlos Jan./Fev. 2008.

[7] Peter Buckle Ergonomics and musculoskeletal disorders: overview.Occup Med (Lond) (May 2005) 55 (3): 164-167R

[8] F.A. Pinheiro, BT Tróccoli, C.V. Carvalho. Validação do Questionário Nórdico de Sintomas Osteomusculares como Medida de Morbidade. Revista Saúde Pública 2002.

[9] J.J. O Toscano;, E.P. Egypto. A influência do sedentarismo na prevalência de lombalgia. Rev. Bras Med. Esporte Niterói Jul./Ago. 2001.

[10] A.C. C Maciel; M.B Fernandes; L.S Medeiros. Prevalência e fatores associados à sintomatologia dolorosa entre profissionais da indústria têxtil. Rev. bras. epidemiol. v.9 n.1 São Paulo mar. 2006.

[11] P. Leino-Arjas Smoking and musculoskeletal disorders in the metal industry: a prospective study Occup Environ Med. 1998 December.

[12] C.H. Gallasch, N.M.C. Alexandre. Avaliação dos riscos ergonômicos durante a movimentação e transporte de pacientes em diferentes unidades hospitalares. Rev. enferm. UERJ. 2003. 